\section{Determination of Optimum Fertilizer Concentration and Corresponding Substrate Electrical Conductivity for Ten Taxa of Herbaceous Perennials}

\author{
Holly L. Scoggins \\ Department of Horticulture, Virginia Tech, Blacksburg, VA 24061
}

Additional index words. pour-through, media testing, soilless media

\begin{abstract}
Little taxa-specific information is available regarding the nutrition needs of container-grown herbaceous perennials. The goal was to determine optimum fertilizer concentrations and corresponding substrate testing values for greenhouse production of 10 taxa. Astilbe chinensis (Maxim.) Franch. \& Savat.'Purpurkerze', Campanula carpatica Jacq. 'Deep Blue Clips', Coreopsis verticillata L.' Golden Gain', Gaura lindheimeri Engelm. \& Gray, 'Siskiyou Pink', Heuchera sanguinea Engelm. 'Mt St. Helens', Lamium maculatum L. 'White Nancy', Penstemon $\times$ hybridus Hort. 'Sour Grapes', Perovskia atriplicifolia Benth. 'Longin', Salvia nemerosa L. 'Blue Hill', and Veronica $\times$ Hort. 'Goodness Grows' were grown for 10 weeks with $15 \mathrm{~N}-7 \mathrm{P}-14 \mathrm{~K}$ at four rates $\left(50,150,250\right.$, and $350 \mathrm{mg} \cdot \mathrm{L}^{-1}$ N) of constant liquid feed. Substrate $\mathrm{pH}$ and soluble salts levels were measured weekly using the pour-through extraction method. In analysis of all taxa, most effects [quality, shoot dry weight, $\mathrm{pH}$ and electrical conductivity (EC)] varied by rate $\times$ taxa. Though higher levels of fertilizer produced the largest plants in some cases, satisfactory quality was also attained with a lower rate. Quality and $\mathrm{pH}$ were negatively correlated for a few genera but most showed no relationship. Results of this study indicate not all taxa tolerate increased fertilizer levels and that the herbaceous perennials studied could be grouped by nutritional needs. Furthermore, target ranges for EC can be developed based on dry mass and quality ratings.
\end{abstract}

The goal of any fertilizer regimen for containerized ornamentals is to provide sufficient but not excessive levels of essential nutrients. As nutrient and water management becomes increasingly regulated, growers will need to justify and account for these production inputs (Lea-Cox, et al., 2001). For floricultural crops, root substrate testing should be conducted every two weeks and the results plotted to detect trends in $\mathrm{pH}$ and soluble salts level (Nelson, 2003). For many floriculture crops, current substrate $\mathrm{pH}$ and soluble salts interpretation ranges are based on 1) 2 water : 1 substrate (v/v) suspension (Sonneveld, 1990); 2) the saturated media extract (SME) method (Warncke, 1986); or 3) the pour-through extraction method (Wright, 1986). With the advent of the pour-through solution extraction method, substrate testing of container-grown ornamental crops is easier and more efficient, allowing for frequent monitoring of root-zone $\mathrm{pH}$ and soluble salts as measured by electrical conductivity (EC) (Wright, 1986). However, for greenhouse production of herbaceous perennials, optimum fertility levels for each species and the subsequent substrate testing

Received for publication 21 May 2004. Accepted for publication 27 Sept. 2004. The research reported herein was funded in part by the Fred C. Gloeckner Foundation, Inc., the Virginia Agriculture Council, and the Virginia Nursery and Landscape Association. Plant material supplied by Yoder-Greenleaf, Inc. Mention of products does not imply endorsement of these products over similar products by Virginia Tech. The author gratefully acknowledges the technical assistance of Velva Groover. guidelines for the pour-through extraction method have not been determined. With the tremendous diversity of herbaceous perennial species grown, knowledge of target $\mathrm{pH}$ and EC ranges can help reduce fertilizer inputs as growers can group crops by nutritional needs, just as with irrigation requirements (Bilderback et al., 1994). Substrate chemical properties' guidelines exist for many bedding plants and potted flowering crops, utilizing the pour-through method (Cavins et al., 2000), but few have been published for herbaceous perennial taxa. The objectives of this study were 2-fold: 1) find fertilizer levels that provides acceptable growth and quality for each taxa and 2) develop associated EC interpretive ranges for use with the pour-through method of substrate testing.

\section{Materials and Methods}

Vegetatively propagated liners of 10 herbaceous perennial taxa (Astilbe chinensis 'Purpurkerze', Campanula carpatica 'Deep Blue Clips', Coreopsis verticillata 'Golden Gain', Gaura lindheimeri 'Siskiyou Pink', Heuchera $\times$ 'Mt St. Helens', Lamium maculatum 'White Nancy', Penstemon $\times$ 'Sour Grapes', Perovskia atriplicifolia 'Longin', Salvia nemerosa 'Blue Hill', and Veronica $\times$ 'Goodness Grows') were received as rooted cuttings (Yoder-Greenleaf, Inc., Lancaster, $\mathrm{Pa}$.). The liners were transplanted into 2.83-L pots with Sierra Perennial Mix (sphagnum peat, aged bark, perlite; initial leachate EC of 1.8 $\mathrm{dS} \cdot \mathrm{m}^{-1}$ and $\mathrm{pH}$ of 6.2 using the pour-through extraction method ) (Scotts Co., Marysville, Ohio). Plants were grown in a glass greenhouse for 10 weeks under late spring greenhouse conditions in Blacksburg, Va. with temperature set points of $23{ }^{\circ} \mathrm{C}$ day $/ 14{ }^{\circ} \mathrm{C}$ night.

The experimental design was a split plot with fertilizer rates (4) as the whole plot factor and taxa (10) as the subplot factor. Fertilizer treatments were arranged in an RCBD with four replicates for a total of 160 experimental units (pots). The fertilizer treatments consisted of four fertilizer rates, 50, 150, 250, and $350 \mathrm{mg} \cdot \mathrm{L}^{-1} \mathrm{~N}$, from $15 \mathrm{~N}-7 \mathrm{P}-14 \mathrm{~K}$ (Peter's 15-16-17, Scotts) with resulting fertilizer solution ECs of $0.34,1.03,1.72$, and 2.41 $\mathrm{dS} \cdot \mathrm{m}^{-1}$, respectively. This complete (includes micronutrients) fertilizer contains $8.03 \%(\mathrm{w} / \mathrm{w})$ $\mathrm{NO}_{3}{ }^{-} \mathrm{N}$ and $6.97 \%$ ammoniacal $\mathrm{N}$, with a slight potential acidity of 195 (defined as pounds of $\mathrm{CaCO}_{3}$ equivalent neutralized by one ton of fertilizer). The fertilizer was mixed with greenhouse tap water (avg. $\mathrm{pH}$ 7.3; alkalinity $1.2 \mathrm{meq} \cdot \mathrm{L}^{-1} \mathrm{CaCO}_{3}$ ) and applied as constant liquid feed at each irrigation event (overhead, by hand) in aliquots of $450 \mathrm{~mL}$ (increased to $550 \mathrm{~mL}$ for some taxa by W6) to maintain a 0.2 to 0.3 leaching fraction. The fertilizer solution aliquots were applied based on daily water loss (Tyler et al., 1996). Time to irrigate was determined by weighing one container of each taxa from each block and comparing that weight to container capacity weight (determined every 2 weeks to account for plant growth). Fertilizer solution was applied when pot weight was $<60 \%$ of container capacity.

Data collected from each experimental unit included $\mathrm{pH}$ and $\mathrm{EC}$ of root zone solution (weekly) and shoot dry weight (DW) at termination of both studies [ten weeks after transplanting (WAT)]. The pour-through method was used to extract root-zone solution for $\mathrm{pH}$ and $\mathrm{EC}$ analyses (Wright, 1986). One h after fertilizer treatment application, distilled water was poured onto the surface of the substrate (150 mL for $2.83-\mathrm{L}$ pots). Leachate was collected in a vinyl saucer placed under the pot. About $50 \mathrm{~mL}$ of leachate were transferred to individual beakers and $\mathrm{pH}$ and $\mathrm{EC}$ was measured (HI9811; Hanna Instruments, Ann Arbor, Mich.).

Quality ratings were also assigned relative to other plants within a particular taxon at termination of each study: $0=$ dead, $1=$ poor quality, extensive chlorosis, necrosis, or other disorders; 2 = some chlorosis/necrosis; $3=$ good condition with relatively little chlorosis or necrosis; 4 = excellent condition. Days to visible bud were also noted, though several of the species/cultivars used in these experiments did not flower; nor was temperature/photoperiod adjusted to meet any individual taxon's flowering requirements. To determine dry weight, shoots were removed at the substrate line at termination of the experiments, placed in a forced-air dryer at $60{ }^{\circ} \mathrm{C}$ for $72 \mathrm{~h}$, and then weighed.

Data were analyzed for analysis of variance (ANOVA) using the general linear model procedure (GLM) of the SAS system v8.2 (SAS Institute, Cary, N.C.) with main effects and interaction evaluated at $\alpha=0.05$. Regression 
Table 1. Effect of fertilizer rate on substrate leachate $\mathrm{pH}$, electrical conductivity (EC), quality rating (Q), and shoot dry weight (DW) of 10 taxa of herbaceous perennials.

\begin{tabular}{lrcccc}
\hline & & \multicolumn{4}{c}{ Mean square } \\
\cline { 3 - 6 } Source & df & $\mathrm{pH}^{\mathrm{z}}$ & $\mathrm{EC}$ & $\mathrm{Q}$ & $\mathrm{DW}$ \\
\hline Block (B) & 3 & 0.08 & 0.53 & 0.18 & 25.2 \\
Fertilizer rate (F) & 3 & $22.7^{* *}$ & $256.36^{* *}$ & $1.94^{* *}$ & $352.70^{* *}$ \\
$\mathrm{~B} \times \mathrm{F}$ (error A) & 9 & 0.17 & 0.22 & 0.08 & 31.70 \\
Taxa (T) & 9 & $0.21^{* *}$ & $6.57^{* *}$ & $1.75^{* *}$ & $785.03^{* *}$ \\
$\mathrm{~F} \times \mathrm{T}$ & 27 & $0.06^{* *}$ & $2.44^{* *}$ & $0.67^{*}$ & $48.54^{* *}$ \\
$\mathrm{~T} \times \mathrm{B}$ (F) (error B) & 105 & 0.01 & 0.52 & 0.39 & 16.71 \\
\hline
\end{tabular}

${ }^{\mathrm{z}} \mathrm{pH}$ and $\mathrm{EC}$ means from duration of experiment.

${ }^{y} \mathrm{~F}$ tests of Block and Fertilizer rate uses $\mathrm{B} \times \mathrm{F}$ (error A) as the error term using Type III MS.

${ }^{* * * * *}$ Nonsignificant or significant at $P \leq 0.05$ or 0.01 , respectively.

Table 2. Influence of fertilizer rate on shoot dry weight (DW), quality (scale $0=$ dead through $4=$ excellent), substrate leachate $\mathrm{pH}$ and electrical conductivity (EC) on 10 taxa of herbaceous perennials. Values are means of four replications.

\begin{tabular}{|c|c|c|c|c|c|}
\hline Taxon & $\begin{array}{l}\text { Fertilizer } \\
\text { rate } \\
\left(\mathrm{mg} \cdot \mathrm{L}^{-1} \mathrm{~N}\right)\end{array}$ & $\begin{array}{c}\mathrm{DW}^{\mathrm{z}} \\
(\mathrm{g})\end{array}$ & Quality & $\mathrm{pH}^{\mathrm{y}}$ & $\begin{array}{c}\mathrm{EC} \\
\left(\mathrm{dS} \cdot \mathrm{m}^{-1}\right)\end{array}$ \\
\hline \multirow[t]{5}{*}{ Astilbe chinensis 'Purpurkerze' } & 50 & 16.3 & 3.25 & 6.7 & 0.5 \\
\hline & 150 & 19.4 & 4.00 & 5.9 & 1.9 \\
\hline & 250 & 18.5 & 3.25 & 5.5 & 3.6 \\
\hline & 350 & 15.9 & 2.38 & 5.3 & 4.3 \\
\hline & Response & NS & $\mathrm{Q}^{* *}$ & $\mathrm{~L}^{* *}$ & $\mathrm{~L}^{* *}$ \\
\hline \multirow[t]{5}{*}{ Campanula carpatica 'Blue Clips' } & 50 & 5.15 & 3.38 & 6.6 & 0.5 \\
\hline & 150 & 9.10 & 4.00 & 6.0 & 1.5 \\
\hline & 250 & 9.58 & 4.00 & 5.5 & 2.7 \\
\hline & 350 & 4.68 & 2.75 & 5.2 & 3.4 \\
\hline & Response & $\mathrm{Q}^{* *}$ & $Q^{*}$ & $\mathrm{~L}^{* *}$ & $\mathrm{~L}^{* *}$ \\
\hline \multirow[t]{5}{*}{ Coreopsis verticillata 'Golden Gain' } & $\quad 50$ & 6.25 & 2.50 & 6.4 & 0.8 \\
\hline & 150 & 10.3 & 3.00 & 5.9 & 2.3 \\
\hline & 250 & 9.23 & 2.75 & 5.5 & 3.7 \\
\hline & 350 & 10.83 & 2.75 & 5.2 & 4.9 \\
\hline & Response & $\mathrm{L}^{*}$ & NS & $\mathrm{L}^{* *}$ & $\mathrm{~L}^{* *}$ \\
\hline \multirow[t]{5}{*}{ Gaura lindheimeri 'Siskiyou Pink' } & 50 & 12.6 & 3.75 & 6.6 & 0.5 \\
\hline & 150 & 15.2 & 3.75 & 6.1 & 2.1 \\
\hline & 250 & 10.8 & 3.50 & 5.4 & 3.6 \\
\hline & 350 & 17.7 & 3.75 & 5.2 & 5.9 \\
\hline & Response & NS & NS & $\mathrm{L}^{* *}$ & $\mathrm{~L}^{* *}$ \\
\hline \multirow[t]{5}{*}{ Heuchera $\times$ 'Mt St. Helens' } & 50 & 22.6 & 3.75 & 6.5 & 0.5 \\
\hline & 150 & 26.4 & 4.00 & 5.9 & 2.0 \\
\hline & 250 & 22.3 & 4.00 & 5.5 & 3.4 \\
\hline & 350 & 20.6 & 4.00 & 5.2 & 4.3 \\
\hline & Response & NS & NS & $\mathrm{L}^{* *}$ & $\mathrm{~L}^{* *}$ \\
\hline \multirow[t]{5}{*}{ Lamium maculatum 'White Nancy' } & 50 & 15.0 & 2.50 & 6.6 & 0.5 \\
\hline & 150 & 27.7 & 3.25 & 6.1 & 1.2 \\
\hline & 250 & 33.5 & 2.67 & 5.7 & 2.7 \\
\hline & 350 & 33.6 & 4.00 & 5.3 & 4.6 \\
\hline & Response & $\mathrm{L}^{* *}$ & NS & $\mathrm{L}^{* * *}$ & $\mathrm{~L}^{* *}$ \\
\hline \multirow[t]{5}{*}{ Penstemon $\times$ 'Sour Grapes' } & 50 & 17.7 & 3.25 & 6.6 & 0.5 \\
\hline & 150 & 28.4 & 3.75 & 5.9 & 2.1 \\
\hline & 250 & 27.8 & 3.75 & 5.5 & 3.7 \\
\hline & 350 & 31.6 & 3.50 & 5.2 & 5.1 \\
\hline & Response & NS & NS & $\mathrm{L}^{* *}$ & $\mathrm{~L}^{* *}$ \\
\hline \multirow[t]{5}{*}{ Perovskia atriplicifolia 'Longin' } & 50 & 11.5 & 3.38 & 6.5 & 0.6 \\
\hline & 150 & 14.2 & 3.25 & 5.9 & 2.0 \\
\hline & 250 & 13.2 & 3.25 & 5.6 & 3.4 \\
\hline & 350 & 11.6 & 3.25 & 5.3 & 4.3 \\
\hline & Response & $\mathrm{Q}^{*}$ & NS & $\mathrm{L}^{* *}$ & $\mathrm{~L}^{* *}$ \\
\hline \multirow[t]{5}{*}{ Salvia nemerosa 'Blue Hill' } & 50 & 12.6 & 3.00 & 6.6 & 0.4 \\
\hline & 150 & 22.6 & 3.75 & 6.3 & 1.6 \\
\hline & 250 & 28.0 & 3.75 & 5.7 & 4.5 \\
\hline & 350 & 28.5 & 4.00 & 5.4 & 5.7 \\
\hline & Response & $\mathrm{L}^{* *}$ & $\mathrm{~L}^{* *}$ & $\mathrm{~L}^{* *}$ & $\mathrm{~L}^{* *}$ \\
\hline \multirow[t]{5}{*}{ Veronica $\times$ 'Goodness Grows' } & 50 & 10.1 & 2.38 & 6.6 & 0.4 \\
\hline & 150 & 15.33 & 3.75 & 6.2 & 1.6 \\
\hline & 250 & 17.4 & 3.75 & 5.7 & 2.9 \\
\hline & 350 & 15.7 & 3.63 & 5.5 & 4.0 \\
\hline & Response & $\mathrm{L}^{* * *}$ & $\mathrm{~L}^{* *}, \mathrm{Q}^{*}$ & $\mathrm{~L}^{* *}$ & $\mathrm{~L}^{* *}$ \\
\hline
\end{tabular}

${ }^{2} \mathrm{DW}$ and $\mathrm{Q}$ at week 10.

${ }_{\mathrm{pH}}$ and $\mathrm{EC}$ values from week 8 .

NS,,*** Significant at $P \leq 0.05$ or 0.01 , respectively; $\mathrm{L}=$ linear; $\mathrm{Q}=$ quadratic. analysis was performed over fertilizer rates to measure the variable responses of dry weight (DW), quality (Q), $\mathrm{pH}$, and EC. Pearson's correlation coefficients (CORR) were used to examine the relationships between variables.

\section{Results and Discussion}

All effects (DW, Q, pH and EC) were different for rate $\times$ taxa (Table 1$)$. Fertilizer rates significantly affected shoot dry weight for Campanula, Coreopsis, Lamium, Perovskia, Salvia and Veronica, but not for Astilbe, Gaura, Heuchera and Penstemon. For the taxa that regression analysis reported as nonsignificant, all showed an increase in DW as the $\mathrm{N}$ rate increased from 50 to $150 \mathrm{mg} \cdot \mathrm{L}^{-1}$, but response varied after that point. Rose et al. (1999) reported that several studies have found poor relationships between plant biomass and ascending fertilizer rates, most likely due to sensitivity to high substrate salt content.. Conversely, many species of herbaceous perennials can become too large and unwieldy, with excessive growth at higher rates of fertilizer. None of the taxa exhibited excessive shoot growth over the span of this study.

Electrical conductivity. Species had a significant effect on EC, illustrating the species-dependent variation in nutrient uptake (van Iersel et al., 1998). Maintaining a constant EC over time can be challenging. Level of salts typically increase when nutrients are supplied faster than the plants can absorb them (van Iersel, 1999). Conductivity readings remained fairly consistent over time until weeks nine and ten, hence the use of week 8 values in table 2 . The aliquot of fertilizer solution applied was not sufficient to prevent soluble salts from building up toward the end of the experiment.

For a set of variable pairs, the correlation coefficient $(r)$ is a good indicator of the strength of the association, whether negative or positive, and is useful in further describing the data. Correlations between dry weight and EC (mean over course of experiment for that taxa) were relatively strong for Coreopsis $(r$ $=0.64)$, Lamium $(r=0.75)$, Penstemon, $(r=$ $0.58)$, Salvia $(r=0.86)$, and Veronica $(r=0.68)$, but not for Astilbe $(r=-0.01)$, Campanula $(r$ $=0.07)$, Gaura $(r=0.35)$ and Perovskia $(r=$ $0.15)$, and negatively for Heuchera $(r=-0.34)$. As visual quality and appeal is generally related to plant mass, there was a strong relationship between DW and Q for all taxa (r values from 0.53 to 0.80$)$ except for Coreopsis $(r=0.40)$, Gaura $(r=0.43)$, Heuchera $(r=0.36)$, and Penstemon $(r=0.24)$.

$\mathrm{pH}$. Plants can influence the $\mathrm{pH}$ of the root zone over time (Huang et al., 2001). By the end of the experiment, mean $\mathrm{pH}$ ranged from 6.7 to 5.2, depending on the fertilizer rate and species (Table 2). Optimal $\mathrm{pH}$ ranges for floriculture crops grown in soilless media usually falls between 5.4 and 6.3 (Bailey and Bilderback, 1997). There was a consistent linear decrease in substrate $\mathrm{pH}$ as fertilizer rate ascended, and $\mathrm{EC}$ and $\mathrm{pH}$ were highly and negatively correlated ( $r$ values from -0.95 to -0.99 ) by week 10 as expected with an acidresidue fertilizer. Note the $\mathrm{pH}$ for the $50 \mathrm{mg} \cdot \mathrm{L}^{-1}$ 
Table 3. Suggested electrical conductivity (EC) ranges for substrate solution extracted using the pour-through method for 10 taxa of herbaceous perennials. Arranged by ascending EC values.

\begin{tabular}{lc}
\hline Taxon & $\begin{array}{c}\text { EC range } \\
\left(\mathrm{dS} \cdot \mathrm{m}^{-1}\right)\end{array}$ \\
\hline Campanula carpatica 'Blue Clips' & $1.5-2.7$ \\
Astilbe chinensis 'Purpurkerze' & $1.8-2.7$ \\
Heuchera $\times$ 'Mt. St. Helens' & $1.9-2.9$ \\
Coreopsis verticillata 'Golden Gain' & $2.1-3.1$ \\
Perovskia atriplicifolia 'Longin' & $2.1-3.2$ \\
Gaura lindheimeri 'Siskiyou Pink' & $2.2-3.3$ \\
Penstemon x 'Sour Grapes' & $2.2-3.3$ \\
Lamium maculatum 'White Nancy' & $2.7-4.1$ \\
Veronica $\times$ 'Goodness Grows' & $2.8-4.2$ \\
Salvia nemerosa 'Blue Hill' & $3.6-5.1$ \\
\hline
\end{tabular}

rate was relatively high (6.4 to 6.6), even at week 10 , probably due to the relatively high $\mathrm{pH}$ of the tap water (7.0 to 7.5 throughout the experiment) used in the fertilizer solution. However, no symptoms associated with low substrate $\mathrm{pH}$, such as nutrient deficiencies or toxicities, were observed. In most cases there was a significant correlation between $\mathrm{pH}$ and DW ( $r$ values from -0.68 to -0.88 ) but this was probably not a causal relationship. Plant responses were likely affected more by EC than by $\mathrm{pH}$. Since $\mathrm{EC}$ and $\mathrm{pH}$ were not independent of each other, an optimal $\mathrm{pH}$ range cannot be determined from these data. Working with pansies (Viola $\times$ wittrockiana Gam.), van Iersel (1999) found leachate $\mathrm{pH}$ dropped to 5.2 by the end of a 6-week experiment when EC was maintained at $1.2 \mathrm{dS} \cdot \mathrm{m}^{-1}$ or higher, at no detriment to the growth of the plants. Recommendations for substrate $\mathrm{pH}$ varies. Nelson (2003) notes the best $\mathrm{pH}$ range for soilless substrates is 5.4 to 6.5. Bailey and Bilderback (1997) state the optimal $\mathrm{pH}$ range for floriculture crops grown in soilless substrate usually falls between 5.4 and 6.3. Biernbaum and Morrison (1999) recommend a $\mathrm{pH}$ range of 5.8 to 6.5 for greenhouse-grown herbaceous perennials, noting excess $\mathrm{Fe}$ or $\mathrm{Mn}$ accumulation in the tissue of some species sensitive to low $\mathrm{pH}$. With the exception of the highest fertilizer rate, $\mathrm{pH}$ results throughout the experiment remained between the lowest and highest of the recommended ranges.

As fertilizer formulations and ratios vary, guidelines for growers are usually range of substrate solution ECs rather than specific $\mathrm{mg} \cdot \mathrm{L}^{-1} \mathrm{~N}$. Most greenhouse crop recommendations for optimal soluble salts levels have been determined using the saturated media extract method (SME). Electrical conductivity levels measured with the pour-through method are consistently higher (Yeager et al, 1983). Relative nutrient requirements for many common greenhouse crops, as compared to the SME method, have previously been divided into light $\left(1.0\right.$ to $\left.2.6 \mathrm{dS} \cdot \mathrm{m}^{-1}\right)$, medium $\left(2.0\right.$ to $\left.3.5 \mathrm{dS} \cdot \mathrm{m}^{-1}\right)$, and heavy $\left(2.6\right.$ to $\left.4.6 \mathrm{dS} \cdot \mathrm{m}^{-1}\right) \mathrm{EC}$ ranges for use with the pour-through method (Cavins, et al. 2000). But several of the taxa tested did not fit into these categories, for example Campanula had the greatest dry weight and quality with an average EC from 1.5 to $2.3 \mathrm{dS} \cdot \mathrm{m}^{-1}$, which makes it a borderline light-medium crop. For the purposes of this study, a specific optimalEC range for each individual taxon was assigned for use with the pour-through solution extraction method (Table 3). Electrical conductivity values measured using the SME method would be slightly lower (Lang, 1996). Each of the taxa grown has been placed in a relative category based on the optimum or point of plateau of dry weight $\pm 0.20 \%$ of the substrate solution EC averaged over time for that fertilizer rate. Since the range of fertilizer rates did not significantly affect DW for Astilbe, or DW and Q for Gaura and Heuchera, lower fertilizer levels are suggested. However, these taxa demonstrated an increase in mean shoot dry weight as fertilizer rate increased from 50 to $150 \mathrm{mg} \cdot \mathrm{L}^{-1} \mathrm{~N}$, and all $\mathrm{Q}$ ratings increased as well, suggesting a minimum substrate EC threshold for optimal growth, probably falling between the values obtained with 50 and $150 \mathrm{mg} \cdot \mathrm{L}^{-1} \mathrm{~N}$. Though regression analysis yielded a non-significant DW or Q response to rate by Penstemon, plants grown at the lowest rate were $30 \%$ to $40 \%$ smaller than those at the higher rates. Only Salvia showed concurrent linear increases in both DW and Q as rates ascended, hence the higher recommended range. Finally, though EC ranges vary for most taxa, growers could group those with overlapping values under the same fertilizer regimen to simplify execution of these recommendations.

\section{Literature Cited}

Bailey, D.A. and T. Bilderback. 1997. Alkalinity control for irrigation water used in nurseries and greenhouses. N.C. Coop. Ext. Serv. Hort. Info. Lflt. 558.

Biernbaum, J. and M. Morrison. 1999. Forcing perennials: Root zone management. Greenhouse Grower 17(1):161-164.

Bilderback, T.E., R.E. Bir, and J.T. Midcap, 1994. Managing drought on nursery crops. N.C. Coop. Ext. Serv. Bul. AG-519-6.

Cavins, J.T., B.E. Whipker, W.C. Fonteno, B. Harden, I. McCall, and J.L. Gibson. 2000. Monitoring and managing $\mathrm{pH}$ and EC using the PourThru extraction method. N.C. Coop. Ext. Serv. Hort. Info. Lfit. 590.

Huang, J.S., P.W. Nelson, and J.W. Lee. 2001. Seedling effect on root substrate $\mathrm{pH}$. J. Plant Nutr. 24:1133-1147.

Lang, H.J. 1996. Growing media testing and interpretation, p. 123-139. In: D.W. Reed (ed.). Water, media, and nutrition for greenhouse crops. Ball, Batavia, Ill.

Lea-Cox, J.D., D.S. Ross, K.M. Teffeau, and E.N. Varley. 2001. Water and nutrient management planning-A new paradigm for the nursery and greenhouse industries. GPN 3:46-51.

Nelson, P.V. 2003. Greenhouse operations and management. 6th ed. Prentice Hall, Upper Saddle River, N.J.

Rose, M.A., M. Rose, and H. Wang. 1999. Fertilizer concentration and moisture tension affect growth and foliar $\mathrm{N}, \mathrm{P}$, and $\mathrm{K}$ contents of two woody ornamentals. HortScience 34:246-250.

Sonneveld, C. 1990. Estimating quantities of watersoluble nutrients in soils using a specific $1: 2$ by volume extract. Commun. Soil Sci. Plant Anal. 21:1257-1265.

Tyler, H.H., S.L. Warren, and T.E. Bilderback. 1996. Reduced leaching fractions improve irrigation use efficiency and nutrient efficacy. J. Environ. Hort. 14:199-204.

van Iersel, M. 1999. Fertilizer concentration affects growth and nutrient composition of subirrigated pansies. HortScience 34:660-663.

van Iersel, M.W., R.B. Beverly, P.A. Thomas, J.G. Latimer, and H.A. Mills. 1998. Fertilizer effects on the growth of impatiens, petunia, salvia, and vinca plug seedlings. HortScience 33:678-682.

Warncke, D.D. 1986. Analyzing growth media by saturation extraction procedure. HortScience 21:223-225.

Wright, R.D. 1986. The pour-through nutrient extraction procedure. HortScience 21:227-229.

Yeager, T.H., R.D. Wright, and S.J. Donohue. 1983. Comparison of pour-through and saturate pine bark extract N, P, K, and pH levels. J. Amer. Soc. Hort. Sci. 108:112-114. 